\title{
Mercury cycling in the terrestrial, aquatic and atmospheric environment of the Slovak Republic - an overview
}

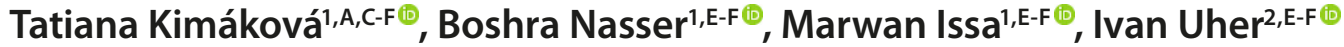 \\ ${ }^{1}$ Faculty of Medicine, Department of Public Health and Hygiene, Pavol Jozef Šafárik University, Košice, Slovakia \\ ${ }^{2}$ Institute of Physical Education and Sport, Pavol Jozef Safarik University, Kosice, Slovakia \\ A - Research concept and design, B - Collection and/or assembly of data, C - Data analysis and interpretation, \\ $D$ - Writing the article, E - Critical revision of the article, F- Final approval of article
}

Kimáková T, Nasser B, Issa M, Uher I. Mercury cycling in the terrestrial, aquatic and atmospheric environment of the Slovak Republic - an overview. Ann Agric Environ Med. 2019; 26(2): 273-279. doi: 10.26444/aaem/105395

\begin{abstract}
Introduction. Mercury release in the environment is mainly the result of human activity, particularly from coal-fired power stations, residential heating systems, waste incinerators, and as a result of mining for mercury, gold and other metals, which have led to widespread global mercury pollution. Excessive exposure to mercury is associated with a wide range of adverse health effects, including damage to the central nervous system, digestive and immune systems, and to lungs, kidneys, skin and eyes.

Objective. The main aim of the study is to summarize the selected mercury sources in the environment of the Slovak Republic, regarding waste incinerators, landfill waste, crematoria, chemical plants, rivers and soils.

Brief description of state of knowledge. Although the neurologic symptoms of Minamata disease were identified sufficiently for specialists to classify mercury as the causative agent, the acceptance of mercury's environmental impacts will require several decades of research. Several new issues have arisen - the need for energy conservation leads to the use of fluorescent lighting, which contain mercury; emissions driven by increases in coal combustion, incineration and economic development have sent more mercury into the air, soil and water.

Conclusions. Mercury is toxic to human health, posing a particular threat to the development of the child in utero and early in life. The systematic analytical controls of contaminants in water, soil and air are important. The installation of modern cleaning technologies to comply with the maximum emission level can substantially minimized the environmental impact of incinerators. Since human cremation is also an increasing practice, further research on mercury emissions is necessary.
\end{abstract}

\section{Key words}

mercury, incinerators, landfill waste, crematoria, soils, water

\section{INTRODUCTION}

Mercury occurs naturally in the earth's crust, but human activities, such as mining and fossil fuel combustion, have led to widespread mercury pollution. Mercury is a ubiquitous element throughout the biosphere, occurring in the air, water, land, and soil, as well as, within living organisms. Mercury emitted into the air eventually settles into water or onto land where it can be washed into surrounding water. Once deposited, certain microorganisms can change it into methylmercury, a highly toxic form that builds up in fish, shellfish and animals that consume fish. Excessive exposure to mercury is associated with a wide range of adverse health effects, including damage to the central nervous system, digestive and immune systems, and damage to the lungs, kidneys, skin and eyes. Thus, protection of the food chain from contamination by mercury is an important task in the protection of the health of the human population $[1,2,3$, $4,5,6,7]$.

The use of mercury for therapeutic reasons was prevalent until the 20th century when the detrimental effects of its

Address for correspondence: Tatiana Kimáková, Pavol Jozef Šafárik University in Košice, Faculty of Medicine, Department of Public Health and Hygiene, Košice, Slovakia

E-mail: tatiana.kimakova@upjs.sk

Received: 12.09.2018; accepted: 19.02.2019; first published: 12.03.2019 exposure were recognized. In traditional Chinese medicine, mercury is part of a certain preparation under the colloquial name of 'calomel' (mercurous chloride). In certain Caribbean and Latin American traditions (Sanataria, Voodoo, Espiritismo), mercury is used for a range of cultural and religious practices (wearing mercury amulets, sprinkling mercury on the floor, or even adding it to a candle or an oil lamp) including those linked to healthcare, such as the use of mercury to treat intestinal disorders. This is due to the belief that a liquid metal is invested with magical properties. The United States Environmental Protection Agency issued a report on these practices because it presents a serious health risk $[8,9,10,11]$.

A methylmercury poisoning in 1956, called Minamata disease, occurred in humans who ingested fish and shellfish contaminated by methylmercury discharged in waste water from a chemical plant. Although the neurologic symptoms of Minamata disease were identified sufficiently for specialists to classify mercury as the causative agent, the acceptance of mercury's environmental impacts, and recognition of its global dispersal required several decades of research. Regulatory agencies have recognized and reduced emissions from incinerators and other sources. However, several new issues have arisen - the need for energy conservation leads to the use fluorescent lighting which contain mercury; emissions driven by increases in coal combustion and 
economic development have sent more mercury into the air; and increases in atmospheric deposition of mercury in dust are correlated with increases in concentrations of mercury in wildlife $[5,12,13]$.

Mercury exists in many different forms in the environment which produce various patterns of toxicity. The natural sources of mercury include primary sources (volcanoes, topsoils, geothermal sources) and reemission processes over land and sea surfaces (land use changes, meteorological conditions, biomass burning). The anthropogenic sources of mercury include chemical and pharmaceutical production facilities, fossil-fuel fired power plants, ferrous and non-ferrous metals manufacturing facilities, caustic soda production plants, ore processing facilities, paper production, silver and gold production, printing, the fur industry, perfume industry, waste incinerators for urban populations, crematoria, landfills, cement plants, the healthcare industry, amalgam fillings and mercury analysis laboratories $[14,15,16,17]$.

Mercury enters the environment through various sources and monitoring has provided data on concentrations in many environmental substances. The Slovak Republic is divided into administrative units (8 regions, which are divided to 79 districts). The Slovak Environmental Agency is a professional organization focused on environmental protection, environmental policy development and landscape creation, under the principles of sustainable development. There are several ecologically contaminated areas in Slovakia, among them the Central Spiš region, and the regions surrounding cities of Nitra, Michalovce and Strážske [7, 18-28].

\section{OBJECTIVE}

The main objective of this study is to summarize selected sources of mercury in the environment of the Slovak Republic, regarding waste incinerators, landfill waste, crematoria, chemical plants, rivers and soils. Data was collected from several sources of environmental contamination by mercury in the Slovak Republic, whereby the natural and anthropogenic sources of 2,933 communities (138 cities) are analyzed. We summarize mercury cycling in terrestrial, aquatic and atmospheric environments of the Slovak Republic, and exposure and effects in humans and wildlife.

Mercury in waste incinerators of Slovakia. The main aim of incineration is to reduce the volume of municipal waste enter landfills, and to destroy and detoxify the many hazardous organic components within the waste through oxidation. In comparison with other waste treatments, the advantages of incineration include volume reduction, energy recovery, and elimination of pathogenic agents. Incineration of household waste has caused atmospheric mercury emissions. Mercury content in waste varies from one type of waste to another type. Mercury in municipal waste is related to consumer products. Mercury is used in batteries, dental applications, measurement and electronic devices, lamps and other minor applications. The mercury release from municipal solid wastes is based on the disposal (i.e. release by breaking, incineration, landfilling, recollection). Model of mercury flows in waste is shown in Fig. 1 [29, 30, 31, 32].

Slag produced from waste incineration processes could also a source of mercury. Slag has a mercury concentration ranging from $0.02 \mathrm{mg} . \mathrm{kg}^{-1}$ to $7.75 \mathrm{mg} \cdot \mathrm{kg}^{-1}$ and it is mostly used

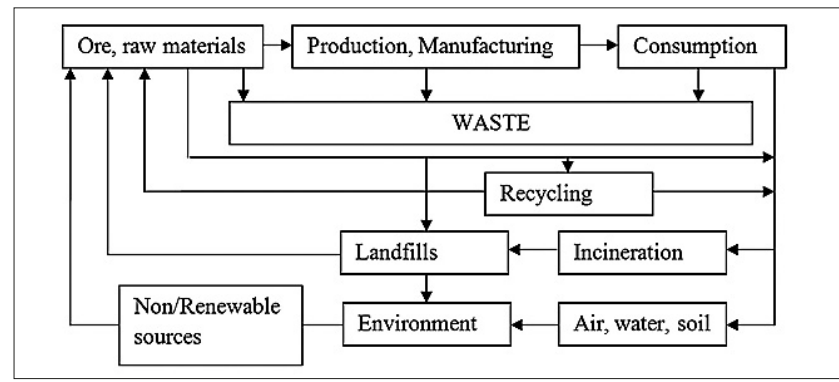

Figure 1. Model of mercury flows in waste (modified from [30])

for road construction, noise barriers, concrete production or landfill material. The total mercury mobilized in slag from waste incinerators in Europe varies between 24 tons - 54 tons, which is partially released to the atmosphere $[29,30,33,34]$.

There are 3 incineration plants for municipal waste in Slovakia - in Bratislava (capacity more than 32 tons per hour), in Košice (10 tons per hour) and in Kysucké Nové Mesto (0.4 tons per hour). Table 1 shows mercury emissions released by these incineration plants in Slovakia from 2016. The evolution in the amount of municipal waste in Slovakia per capita between $2005-2015$ is shown in Fig. 2.

Table 1. Mercury emissions in municipal waste incinerators in Slovakia

\begin{tabular}{|c|c|c|c|c|}
\hline \multirow{2}{*}{$\begin{array}{l}\text { City of waste } \\
\text { incinerator }\end{array}$} & \multirow{2}{*}{$\begin{array}{l}\text { Capacity } \\
\text { in tons } \\
\text { per hour }\end{array}$} & \multicolumn{2}{|c|}{$\begin{array}{l}\text { Mercury emissions in } \\
\text { mg.m }{ }^{-3}\end{array}$} & \multirow{2}{*}{$\begin{array}{l}\text { Limit of mercury } \\
\text { emissions in } \\
\text { Slovakia }\end{array}$} \\
\hline & & boiler 1 & boiler 2 & \\
\hline Bratislava & 32.7 & 0.016 & 0.002 & \multirow{3}{*}{0.05} \\
\hline Košice & 10 & 0.004 & 0.017 & \\
\hline Kysucké Nové Mesto & 0.4 & unknown & Unknown & \\
\hline
\end{tabular}

Slovakia incinerates a relatively small amount of waste compared to the amount enter into landfills. According to the data from 2011, $75 \%$ of municipal waste generated in Slovakia still ended up in landfills (78 \% in 2001). Only approximately $10 \%$ of municipal waste was incinerated with energy recovery (6\% in 2001). Around $7 \%$ of municipal waste was collected selectively. Existing recycling infrastructure is sufficient, but separate collection systems need to be further improved. The total recycling rate is still very low. According to present trends, an exceptional effort will be required to meet the European Union requirement of $50 \%$ municipal waste recycling in 2020 [35, 36, 37].

Forastiere et al. [36] conducted a health impact assessment of incineration in Slovakia. According to their results, 16,000 people lived within $3 \mathrm{~km}$ of the 2 incinerators in Slovakia. In their research, the authors were moderately confident that 24 additional cancer cases will be attributable to incinerators in Slovakia during 2001-2050, and the majority will be due to exposure before 2001. Lower socio-economic status is already associated with a higher risk of various negative health outcomes. The situation for the incinerators in Slovakia is different, since they have an urban location and people living in urban areas tend to have a higher socio-economic status. Thus, the social class distribution around the 2 plants in Slovakia was skewed toward a higher social class [36].

In Slovakia, there are 5 incinerators for industrial waste (Slovnaft in Bratislava has the largest capacity 3.7 tons per hour) and 7 incinerators for medical waste of which 3 have been closed due to the emission limits being exceeded. 


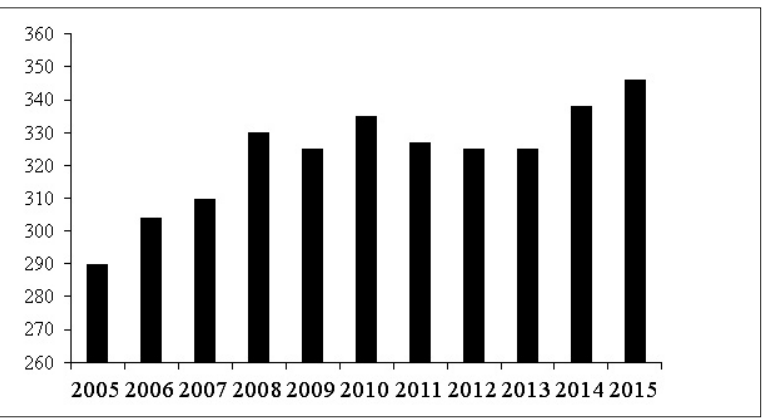

Figure 2. Municipal waste in Slovakia measured in kilogram per individual (20052015) [38]

Incinerators of the University Hospital in Bratislava are currently preparing for reconstruction.

Incinerators release pollutants in the form of exhales, ash and other residues. The filters that are used produce solid liquid toxic waste. The only way to prevent the emergence of toxic waste is to improve production and technology. Public opposition to incinerators is growing worldwide because people are aware that waste incinerators are not consistent with the sustainable development of environmental quality.

Waste landfills in Slovakia. A municipal solid waste landfill is a discrete area of land or excavation that receives household waste. Leachate is formed when rain water filters through waste placed in a landfill and when this liquid comes in contact with buried waste, it leaches chemicals or constituents from that waste. The regulations for landfills include location restrictions to ensure that landfills are built in suitable geological areas. Landfills are also required to have a flexible membrane to protect groundwater and the underlying soil from leachate release. These practices help reduce odour, control litter, insects, and rodents, and protect public health [39].

Landfills are the most well represented method of waste management in Slovakia. Forastiere et al. [36] conducted a health impact assessment of Slovakian landfilling. In 2001 , a total of 328,869 people lived within $2 \mathrm{~km}$ of the 121 landfill plants in Slovakia, most of residents were located in the 1-2 km circumferential zone. Forastiere et al. [36] are moderately confident that the annual additional cases of congenital anomalies up to 2030 will be approximately 2 , in addition there will be 13 additional low-birth weight newborns [36, 38, 40, 41].

The distribution of the landfills in Slovakia in 2013 is shown in Figure 3. There are 118 landfills in Slovakia, which are divided into 3 classes of landfills (inert waste, non-hazardous waste and hazardous waste). Their uneven distribution in territories is reflected in illegal dumps. Landfills have a determined period of activity and several of them will be closed in the upcoming years. Thus, it is necessary to ensure new landfills can be opened in order that the entire territory of Slovakia will be evenly covered. Apart from managed landfills, there are thousands of illegal waste dumps around the country as a long term unsolved problem. In 2014, the mobile application TrashOut located more than 2,000 illegal dumps [38, 40, 42].

Environmental issues are caused by the waste landfills in Zohor (Malacky district), Budmerice (district of Pezinok), Hlohovec, Livinske Opatovce (Partizánske district), Žakovce (Kežmarok district), Kalna nad Hronom and Nový Tekov (district Levice), Žiar nad Hronom, Košice - Myslava, Košice - Západ and Strážske [40].

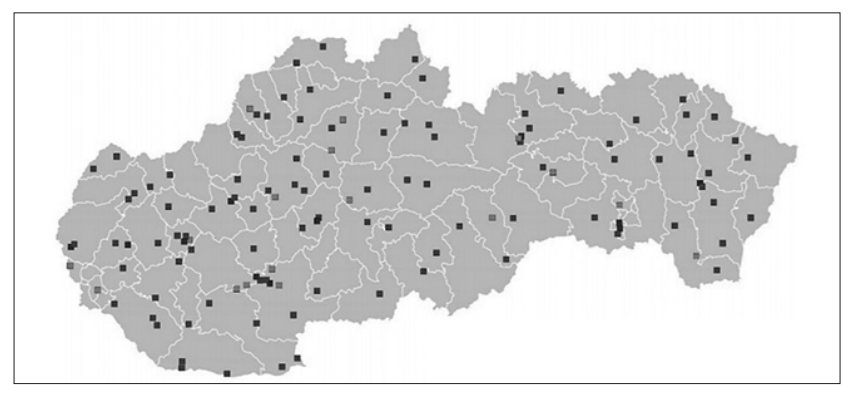

Figure 3. Distribution of landfills in Slovakia in 2013 [40]

The Decree of the Ministry of the Environment of the Slovak Republic No. 372/2015 Coll. [43] on landfills and temporary storage of metallic mercury, specifies the requirements for landfill waste and temporary storage of metallic mercury. When selecting a site for the landfill of waste or temporary storage of metallic mercury, the following criteria must be taken into account: safe distance of the landfill from residential areas or recreational areas, watercourses, water reservoirs and water resources; geological, hydrological, hydrogeologic conditions; protection of nature and possible meteorological impacts [43].

Spent fluorescent lamps should be disposed of in welldesigned and monitored landfills, as mercury emissions from fluorescent lamps buried in these landfills can be contained, captured and treated. However, even those landfills considered as properly constructed pose a risk to the environment and to human health [44].

Mercury in crematoria. Cremation as a method of disposal of dead bodies, dates back to the Neolithic period. One of the earliest known examples of cremation is the 'Mungo Lady' from 40,000 years ago. Cremation practices are accepted in Jainism, Hinduism, Sikhism, Buddhism and Shintoism. Modern cremation has increased in popularity since 1940 as an answer to cemeteries using up valuable land. Due to cultural and religious factors, it is the choice with about $99 \%$ of the population in Japan. In Europe, the highest rate of cremation is in Switzerland, Denmark and the United Kingdom (more than $70 \%)$. In Israel and some other countries there is a very low incidence of cremation $[45,46]$.

A crematorium contains one or more combustion units (so called cremators) used for the cremation of human bodies within special containers. Cremators are made of high-grade steel plate and lined inside with heavy refractory tiles. From the legal point of view, crematoria are not considered as incinerators. However, crematoria have been identified as sources of various environmental pollutants: mercury, polychlorinated dibenzo-p-dioxins, and dibenzofurans, arousing the most interest. In contrast to incineration, for which the various studies on their toxic emissions are available, papers related to mercury emissions from crematoria are very limited $[46,47]$.

Although most elements can be removed from crematorium emissions through special control devices (most cremators have several automatic controls and use gas for heating the cremator), special attention should be paid to the mercury emissions. This heavy metal enters the process because it is present in the body being cremated $(6 \mathrm{mg}$ for the average body). In particular, mercury is emitted during cremation since dental fillings are made with dental amalgam containing more than 0.5 grams of mercury. This metal will leak from 
the fillings because of mercury's low vapour pressure. The dental amalgams are unstable at cremation temperatures $\left(650-700^{\circ} \mathrm{C}\right)$ and free mercury metal is highly volatile. Thus, the intense temperatures of cremation cause the mercury present in the fillings to volatilize $[46,47]$.

It has been suggested that crematoria are responsible for approximately one-sixth of all emissions of mercury in the United Kingdom, largely from the combustion of dental amalgam (Smith, 2012). Studies have reported that in $88 \%$ of patients without dental amalgams, cremation emissions were under the acceptable level of $200 \mathrm{mg} \cdot \mathrm{m}^{-3}$ mercury released. However, in deceased people with amalgam restorations, only $18 \%$ recorded less than the acceptable level of $200 \mathrm{mg} \cdot \mathrm{m}^{-3}[46,48,49]$.

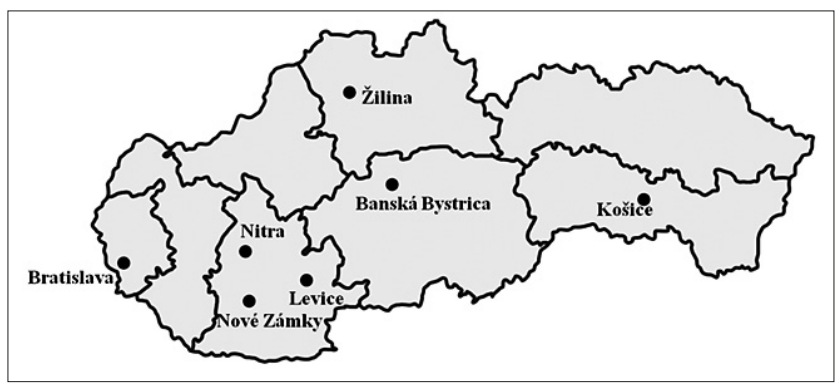

Figure 4. Location of crematoria in Slovakia (2016)

The locations of the 7 crematoria in Slovakia are shown in Fig. 4. These crematoria declare that they respect European Union air quality legislation dating from 2013, which includes national ceiling levels for pollutants and emissions from medium-sized combustion plants. In contrast to incinerators, there are no studies presenting evidence of mercury emissions from crematoria in Slovakia. However, since human cremation is also an increasing practice in Slovakia, research on crematoria is necessary. Modern crematoria should be equipped with filters which completely obviate any environmental hazard; another possibility would be removing the teeth from a dead body before cremation. The impact of new crematorium buildings on air quality should be thoroughly assessed.

Mercury in chemical plants. The Slovak chemical industry is one of the largest sectors of the national economy. Output includes a diverse portfolio of hundreds of different products, ranging from petrochemicals, agrochemicals, primary organic/inorganic chemicals, to rubber, plastic products, drugs and vaccinations. Plants of chemical companies are primarily located in Western and Central Slovakia with the main centres in Bratislava, Trnava, Púchov, Nitra and Žilina. In Eastern Slovakia, the most important centres are Svit and Humenné. Although several chemical plants have recently reduced their activities, the chemical industry is currently located in every region of Slovakia [50].

The former extraction and processing of mercury is a major source of pollution in the area of Central Spiš (district Gelnica and Spišská Nová Ves), which is classified as one of the most affected areas in the Slovak Republic. Around 1895, an iron ore smelting and mercury production plan was founded in Rudňany near Spišská Nová Ves. Production finished, however, in 1992, although the contamination of the environment (especially soils) will take several years to disperse. Former mercury companies in Rudňany have significantly contributed to the fact that the areas of Central Spiš are considered as the most affected areas in the Slovak Republic [51, 52, 53].

The Nováky Chemical Plant was situated in Hornonitrianska Valley in the area of Nováky city with a tradition of manufacturing chemical products dating back to 1940. The main activities of the company were the manufacturing and sales of products, including the production and processing of chlorine, production of calcium carbide and technical gases, the production of polyvinylchlorid and the byproducts of its processing, and the production of special low tonnage chemicals. The Nováky Chemical Plant became known as the source of numerous case studies of liver cancer in workers exposed to vinylchloridmonomer (building block of polyvinylchlorid) in the 1950s and 60s.

Chlorine and sodium hydroxide were produced in the Nováky Chemical Plant via the mercury-cell chloralkali process. Mercury-cell chloralkali electrolysis has a serious effect on the environment. In 2002, analysis confirmed the presence of high levels of mercury (up to $112 \mu \mathrm{g} .1^{-1}$ ) in what appeared to be the main wastewater discharge into the Nitra River (on the western side of the plant). Mercury concentrations in river water 6 kilometers downstream from the plant were recorded to be more than 100 times higher than background concentrations measured upstream [54].

In 2012, The Nováky Chemical Plant changed its name to Fortischem a.s. and the project for the conversion of mercury electrolysis to membrane electrolysis ran continuously from 2014 - 2017. In 2017, Fortischem ended the production of chemical products through the old process of mercury electrolysis. However, the mercury released into the environment will remain a significant concern far into the future.

Mercury in the waters of Slovakia. Clean water is an essential element for human health and prosperity. The surface water resources (rivers, streams, creeks, lakes, and reservoirs) are vitally important as they include drinking-water, and the effect of human activities on surface water quality has been evident for a long time. In Slovakia, the assessment of surface water quality is regulated by Governmental Order No. 269/2010 Coll. which sets up requirements for good water status in the wording of Governmental Order No. 398/2012.

Ružín is a seriously polluted water reservoir with an area of $3.9 \mathrm{~km}^{2}$, and a water volume of 59 million $\mathrm{m}^{3}$, located in Eastern Slovakia. The reservoir was created by damming the Hornád River in 1967 (Ružín I) and 1972 (Ružín II). The Ružín water reservoirs receive toxic elements through the draining of the rivers Hornád and Hnilec within catchment areas polluted with the former extensive mining of ore-bearing deposits. In samples of the sediment load from the Ružín I (main reservoir) and Ružín II (compensatory reservoir) water reservoirs in 2010-2014, indicated that there was significant contamination with various heavy metals. The asp (Leuciscus aspius), the sample with the highest concentration of mercury, occurred in the open waters of rivers and large lakes $[55,56]$.

The Nitra River $(171 \mathrm{~km})$, located in Western Slovakia, is one of the most polluted rivers in the Slovak Republic, classified as extremely heavily polluted water. Very serious anthropogenic pollution occurs in the basin of this river due to the coal-mining, electricity generation and chemical industry $[27,28]$. A map of the most poluted rivers Hornád and Nitra is shown in Figure 5. 


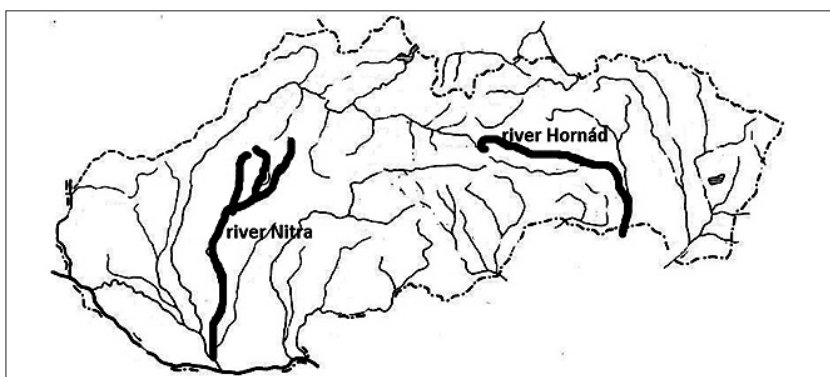

Figure 5. Map of the rivers of Slovakia - Hornád and Nitra, the most polluted rivers.

Mercury in the soils of Slovakia. Historically, mining for mercury, gold and copper has lead to high mercury concentrations in soil samples from Eastern and Central Slovakia. Processing activities have become dangerous in terms of numbers of environmental loads. This fact calls for stricter control of mercury in all parts of the food chain, including soil. The A horizon is the top layer of the soil horizons, often referred to as topsoil. This layer has a coating of dark decomposed organic materials called humus. The occurrence of mercury in the A surface horizon in Slovakia is shown in Fig. 6. The high concentrations of mercury (Central Spiš, Malachov, near Banská Bystrica) are highlighted in dark colours $[13,57,58,59,60]$.

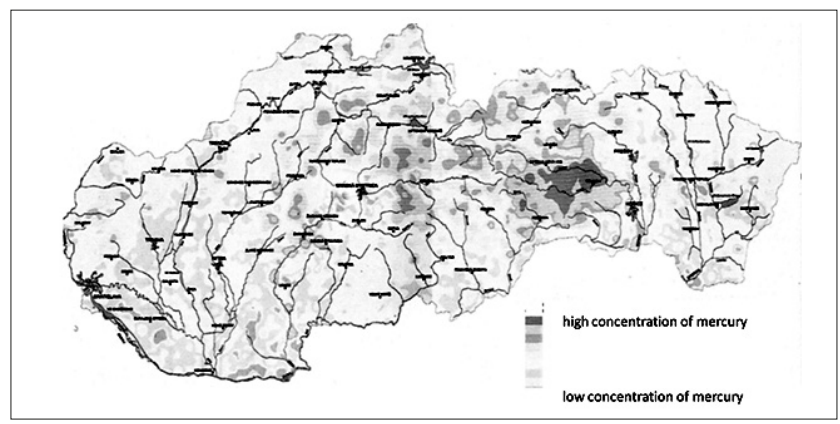

Figure 6. Occurrence of mercury in the A surface horizon in Slovakia [57]

The basic legislation for the protection of agricultural land in Slovakia is Act No. 220/2004 Coll. on the conservation and use of agricultural land, and amending Act No. 245/2003 Coll. concerning integrated pollution prevention and control and amending certain laws, which provides a basic framework for the conservation of agricultural land. This legislation specifies the limit for mercury in arable soil: $0.15 \mathrm{mg} \cdot \mathrm{kg}^{-1}$ for sandy soils, $0.5 \mathrm{mg} . \mathrm{kg}^{-1}$ for silty soils and $0.75 \mathrm{mg} \cdot \mathrm{kg}^{-1}$ for clay soils.

An assessment of the potential impact of geological contamination of the environment on the health of the population in Spišsko-Gemerské rudohorie Mts. is presented by Rapant et al. [61]. They found that the most significant contamination is documented in the soils and stream sediments where the average mercury content is approximately 50 times higher than the Slovak average. A medical study included some 30 health indicators for all 98 municipalities of the study area. Significant correlations between element contents in the geological environment and health indicators, mainly cancer and cardiovascular diseases, were identified [61].

In the current study it was found that mercury in the soils of Štefanská Huta (a part of Kluknava village, Central Spiš) was of the insoluble form. The results show that the mercury
Table 2. Mercury contaminated soil in Slovakia

\begin{tabular}{|c|c|c|c|c|}
\hline $\begin{array}{l}\text { Part of } \\
\text { Slovakia }\end{array}$ & Location & $\begin{array}{c}\text { Maximal mercury } \\
\text { concentration in } \\
\mathrm{mg} \cdot \mathrm{kg}^{-1}\end{array}$ & Source & $\begin{array}{l}\text { Year of } \\
\text { publi- } \\
\text { cation }\end{array}$ \\
\hline \multirow{8}{*}{ Eastern } & \multirow{5}{*}{ Rudňany } & 130 & Maňkovská [51] & 1996 \\
\hline & & $>100$ & Merva and Zaic [63] & 1997 \\
\hline & & 99 & $\begin{array}{l}\text { Angelovičová and } \\
\text { Fazekašová [64] }\end{array}$ & 1998 \\
\hline & & 12.2 & Pavlenda et al. [65] & 2010 \\
\hline & & 30.9 & Urík et al. [66] & 2014 \\
\hline & \multirow[b]{2}{*}{ Central Spiš } & 6.7 & Kobza [67] & 2005 \\
\hline & & 7.8 & $\begin{array}{c}\text { Angelovičová et al. } \\
{[60]}\end{array}$ & 2014 \\
\hline & Krompachy & 30.1 & Vilček et al. [68] & 2012 \\
\hline \multirow{2}{*}{ Central } & Žiar nad Hronom & 2.5 & Dombaiová [52] & 2005 \\
\hline & Malachov & 44.24 & Dadová et al. [69] & 2016 \\
\hline
\end{tabular}

concentrations ranged from $100 \mathrm{mg} \cdot \mathrm{kg}^{-1}-500 \mathrm{mg} \cdot \mathrm{kg}^{-1}$. The concentration of mercury in the soil extract was $10-50 \mathrm{mg}$. $\mathrm{kg}^{-1}[24,25]$. Table 2 shows the mercury concentrations in contaminated soil in Slovakia.

From 1991 - 2012, monitoring in the Slovak Republic focused on the relationship between the degree of contamination of agricultural land, surface water, drinking water, plant and animal production. In total, 53,081 samples were analyzed, $5.7 \%$ of samples exceeded the limit concentrations. Mercury represents a chemical element with the second highest number of over the limit samples, including soils, drinking water, beef liver and grasslands [38, 62].

Lichens are sensitive to a variety of air pollutants and are widely used as biomonitors of air quality, since their mineral nutrition comes mainly from rainfall. In Europe, Hypogymnia physodes has declined in many areas with a significant pollutant load. Melicherčík and Melicherčíková [53] describe that Hypogymnia physodes declined in the area of metallurgical company in Rudňany (Central Spiš) on an area of $6 \mathrm{~km}^{2}$ in 1960, and on an area of $160 \mathrm{~km}^{2}$ in $1980[53,63]$.

\section{CONCLUSIONS}

Mercury is toxic to human health, posing a particular threat to the development of the child in utero and in early in life. Human exposure occurs mainly through inhalation of elemental mercury vapours during industrial processes, and through the consumption of contaminated fish and shellfish. Interventions to prevent environmental release and human exposure include eliminating the production of mercury and its use in mining and industry; promoting instead the use of clean energy sources that do not rely on burning coal, switching to non-mercury thermometers and sphygmomanometers in health care, and implementing safe handling, use and disposal of products and waste containing mercury [64].

The installation of modern cleaning technologies to comply with the maximum emission level can substantially minimize the environmental impact of incinerators. Since human cremation is also an increasing practice, further research on crematoria is still necessary. Modern crematoria should be equipped with filters to completely obviate environmental 
hazard; another possibility would be removing the teeth from a body before cremation. The impact of new crematorium buildings on the air quality should be thoroughly assessed.

\section{Acknowledgements}

The study was completed with the assistance of the Test Laboratory of EL Institute in Spiššká Nová Ves which performs mercury testing and sampling of foodstuff, foods, beverages, and their individual components, biological materials, waste, waters, soils, chemicals, among other materials. The research was partially supported by Cultural and Educational Grant Agency MŠVVaŠ SR, grant number 005UPJŠ-4/2019.

\section{REFERENCES}

1. WHO (World Health Organization). Elemental mercury and inorganic mercury compounds: human health aspects. International Chemical Assessment Document. Geneva, 2003.

2. Polak-Juszczak L. Mercury in fish and fish products. An evaluation of threats to customer health. Oceanol Hydrobiol Stud. 2010; 39: 93-103.

3. Polak-Juszczak L. Chemical Characteristics of Fishes New to the Polish Market. Acta Sci Pol., Piscaria 2007; 6(2): 23-32.

4. Polak-Juszczak L. Bioaccumulation of mercury in the trophic chain of flatfish from the Baltic Sea. Chemosphere 2012; 89: 585-591.

5. Bank MS, ed. Mercury in the Environment: Pattern and Process. University of California Press, 2012.

6. EPA (U.S. Environmental Protection Agency). Mercury biomonitoring. Environmental Protection Agency American's children and the Environment, Third edition, 2015. https:/www.epa.gov/sites/ production/files/2015-10/documents/ace3_mercury.pdf (access: 2018.10.28)

7. Kimáková T, Kuzmová L, Nevolná Z, et al. Fish and fish products as risk factors of mercury exposure. Ann Agric Environ Med. 2018; 25(3): 421-427.

8. Riley DM, Newby CA, Leal-Almeraz TO, et al. Assessing elemental mercury vapor exposure from cultural and religious practices. Environ Health Perspect. 2001; 109:779-784.

9. Davidson PW, Myers GJ, Weiss B. Mercury exposure and child development outcomes. Pediatrics 2004; 13: 1023-1029.

10. Street RA, Kabera GM, Connolly C. Metallic mercury use by South African traditional health practitioners: perceptions and practices. Environmental Health 2015; 14, 7 pages.

11. EPA (U.S. Environmental Protection Agency). EPA and FDA Issue Final Fish Consumption Advice, 2017. https://www.epa.gov/newsreleases/ epa-and-fda-issue-final-fish-consumption-advice-0 (access: 2018.07.15)

12. Mackey TK, Contreras JT, Liang BA. The Minamata Convention on Mercury: Attempting to address the global controversy of dental amalgam use and mercury waste disposal. Sci Total Environ. 2014; 472: 125-129.

13. Tóth G, Hermann T, Da Silva MR, Montanarella L. Heavy metals in agricultural soils of the European Union with implications for food safety. Environ Int. 2016; 88: 299-309.

14. Bencko V, Wagner V, Wagnerová M, Ondrejcák V. Immunological profiles in workers occupationally exposed to inorganic mercury. J Hyg Epidemiol Microbiol Immunol. 1990; 34(1): 1-15.

15. Bencko V, Wagner V. Metals, metalloids and immunity. Methodological approaches and group diagnostics. Centr Europ J Occup Environ Med. 1995; 1(4): 327-337.

16. Bencko V, Novák J, Suk M (Eds.) Health and natural conditions (Medicine and Geology). Praha: Dolin, 2011. (In Czech)

17. Tchounwou PB, Yedjou CG, Patlolla AK, et al. Heavy metal toxicity and the environment. Mol Clin Environ Toxicol. 2012; 101: 133-164.

18. Kimáková T, Bernasovská, K. Fish consumption. Hygiene. 2007; 52(3): 77-79. (In Slovak)

19. Kimáková T. Mercury cycle in nature regarding living organism. INFOVET. 1999; 6(4): 36-38. (In Slovak)

20. Kimáková T. The content of mercury in the muscles of different animal species. Slovakian Vet J. 2000; 25(4): 213-216. (In Slovak)

21. Kimáková T. Analysis of mercury in milk. Proceedings of the 4th Morphological Day in Košice; 2001; Košice, Slovakia. Košice: Pavol Jozef Šafárik University in Košice; 2001. (In Slovak)
22. Kimáková T. Analysis of mercury in non-alcoholic and alcoholic drinks Proceedings of the 4th Morphological Day in Košice; 2002; Košice, Slovakia. Košice: Pavol Jozef Šafárik University in Košice; 2002. (In Slovak)

23. Kimáková T. Effect of mercury to the damage of human organism. Proceeding of the Conference School and Health for 21st Century: General Question of Health Training; 2009; Brno, Czech Republic. Brno: Masaryk University in Brno; 2009. (In Slovak)

24. Kimáková T, Andruch V, Kalavský F. Mercury content in seafood. Proceedings of 2nd International Conference on Mineralurgy and Environmental Technologies; Herlany, Slovakia. Košice: Technical University in Košice; 2001. (In Slovak)

25. Kimáková T, Kalavský F. Mercury and its occurrence in individual parts of selected plants of middle Spiš. In: Using experimental methods to protect and promote the health of the population: Proceedings. Košice: Pavol Jozef Šafárik University in Košice, 2010. pp. 165-171. (In Slovak)

26. Kimáková T, Cimboláková I, Farkašová Iannaccone S et al. Environment and its ethical aspects. Košice: Pavol Jozef Šafárik University in Košice, 2015. (In Slovak)

27. Vollmannova A, Kujovsky M, Stanovic R, et al. Contamination of the Alluvium of the Nitra River in Slovakia by Cadmium, Mercury and Lead as a Result of Previous Intense Industrial Activity. Bull Environ Contam Toxicol. 2016; 97: 561-568.

28. Musilova J, Arway J, Vollmannova A, et al. Environmental Contamination by Heavy Metals in Region with Previous Mining Activity. Bull Environ Contam Toxicol. 2016; 97: 569-575.

29. Mukherjee AB, Zevenhoven R, Brodersen J, et al. Mercury in waste in the European Union: sources, disposal methods and risks. Resources Conserv Recycl. 2004; 42: 155-182.

30. Pironne N, Cinnirella S, Feng X. et al. Global mercury emissions to the atmosphere from anthropogenic and natural sources. Atmos Chem Phys. 2010; 10: 5951-5964.

31. Zhang L, Wang S, Wang L, et al. Updated Emission Inventories for Speciated Atmospheric Mercury from Anthropogenic Sources in China. Environ Sci Technol. 2015; 49(5): 3185-3194.

32. Trasande L, DiGangi J, Evers DC, et al. Economic implications of mercury exposure in the context of the global mercury treaty: Hair mercury levels and estimated lost economic productivity in selected developing countries. J Environ Manage. 2016; 183: 229-235.

33. Hong J, Han X, Chen Y, et al. Life cycle environmental assessment of industrial hazardous waste incineration and landfilling in China. Int J Life Cycle Assess. 2017; 22(7): 1054-1064.

34. Blahuskova V, Vlcek J, Jancar D. Study connective capabilities of solid residues from the waste incineration. J Environ Mana. 2019; 231: 1048-1055.

35. Zsigraiová Z, Tavares G, Semiao V, et al. Municipal solid waste incineration - contribution to sustainable development of energy and environment. Acta Metallurgica Slovaca. 2005; 11:450-459.

36. Forastiere F, Badaloni Ch, Hoogh K, et al. Health impact assessment of waste management facilities in three European countries. Environ Health. 2011; 10:53.

37. Aleksic D. Municipal waste management in Slovakia. European Environment Agency, https://www.eea.europa.eu/publications/ managing-municipal-solid-waste/slovakia-municipal-wastemanagement (access: 2018.11.10)

38. Lieskovská Z, Némethová, et al. State of the Environment Report of the Slovak Republic 2015. Banská Bystrica: Ministry of Environment of the Slovak Republic and Slovak Environmental Agency, 2016. (In Slovak)

39. EPA (U.S. Environmental Protection Agency). Municipal Solid Waste Landfills, 2018 https://www.epa.gov/landfills/municipal-solid-wastelandfills (access: 2018.09.25)

40. Ministry of Environment of the Slovak Republic. Waste Management Program for 2016 - 2020, http://www.minzp.sk/files/sekciaenviromentalneho-hodnotenia-riadenia/odpady-a-obaly/registre-azoznamy/poh-sr-2016-2020_vestnik.pdf (access: 2018.09.13)

41. Szabo S. Situation in Slovak Republic. Position Paper. SOSNA Environmental Education Center, 2016, http://www.humusz.hu/sites/ default/files/Dokumentumok/szakpolitika/ position_paper_sk.pdf (access: 2018.05.16)

42. Bosak M, Krajnak J, Beslerova S. Innovative approach in waste management. 14th SGEM GeoConference on Ecology, Economics, Education And Legislation; 2014 June 19-25; 2014.

43. Decree of the Ministry of the Environment of the Slovak Republic No. $372 / 2015$ Coll. on landfills and temporary storage of metallic mercury, 2015. (In Slovak)

44. Hu Y, Cheng H. Mercury risk from fluorescent lamps in China: Current status and future perspective. Environ Int. 2012; 44: 141-150. 
45. Jones R. Australia felix - The discovery of a pleistocene prehistory. J Hum Evol. 1977; 6: 353-61.

46. Smith TO, et al. The potential dangers of medical devices with current cremation practices. Eur Geriatr Med. 2012; 3: 97-102.

47. Mari M, Domingo JL. Toxic emission from crematories - a review. Environ Int. 2010; 36(1): 131-137.

48. Matter-Grutter C, Baillod R, Imfeld T, et al. Mercury emission measurements in a crematorium. The dentistry aspects. Schweiz Monatsschr Zahnmed 1995; 105: 1023-1028.

49. Černá M, et al. Biomonitoring III. Results of analysis of selected toxic trace elements $(\mathrm{Pb}, \mathrm{Cd}, \mathrm{Hg})$ in the blood of the Czech population. Czech and Slovak Hygiene. 2004; 1: 4-7. (In Czech)

50. Slovak Investment and Trade Development Agency. Overview of Slovak chemical and pharmaceutical industries, 2013, https://www.sario. sk/sites/default/files/content/files/ chemical_industry_0.pdf (access: 2018.09.13)

51. Maňkovská B. Mercury concentrations in forest trees from Slovakia. Water, Air and Soil Pollution. 1996; 89: 267-275.

52. Dombaiová R. Mercury and methylmercury in plants from differently contaminated sites in Slovakia. Plant Soil Environ. 2005; 51: 456-463.

53. Melicherčík M, Melicherčíková D. Impact of the environment and the effects of substances on the human organism. Banská Bystrica: FPV UMB, 2010. 345 p. (In Slovak)

54. Labunska I, Brigden K, Santillo D, et al. The Nováky Chemical Plant (Novácke chemické závody) as a source of mercury and organochlorine contaminants to the Nitra River, Slovakia. Greenpeace Research Laboratories, Department of Biological Sciences, University of Exeter, Exeter EX4 4PS, UK, 2002. 45 pages.
55. Brázová T, Torres J, Eira C, et al. Perch and Its Parasites as Heavy Metal Biomonitors in a Freshwater Environment: The Case Study of the Ružín Water Reservoir, Slovakia. Sensors. 2012; 12(3): 3068-3081.

56. Šestinova O, Findorakova L, Hančulák J, et al. The Water Reservoir Ružín - Accumulation of Priority Pollutants in Sediments in the Years 2010 - 2014. Proc Earth Planetary Sci. 2015; 15: 844-848.

57. Čurlík J, Šefčík P. Geochemical atlas of the Slovak Republic. Land. Ministry of Environment of the Slovak Republic, 1999. (In Slovak)

58. Šefč́́k P, Pramuka S, Gluch A. Assessment of soil contamination in Slovakia according index of geoaccumulation. Agriculture. 2008; 54: 119-130.

59. Takáč P, Kozáková L', Valková M, et al. Heavy metals in the middle Spiš soils. Acta Montan Slovaca. 2008; 13: 82-86. (In Slovak)

60. Angelovičová L, Lodenius M, Tulisalo E, et al. Effect of Heavy Metals on Soil Enzyme Activity at Different Field Conditions in Middle Spis Mining Area (Slovakia). Bull Environ Contam Toxicol. 2014; 93: 670-675.

61. Rapant S, Cvečková V, Dietzová Z, et al. Medical geochemistry research in Spišsko-Gemerské rudohorie Mts., Slovakia. Environ Geochem Health. 2009; 31:11-25.

62. Klinda J, Lieskovská Z, et al. State of the Environment Report of the Slovak Republic 2013. Banská Bystrica: Ministry of Environment of the Slovak Republic and Slovak Environmental Agency, 2013. (In Slovak)

63. Hauck M, Huneck S. Lichen Substances Affect Metal Adsorption in Hypogymnia physodes. J Chem Ecol. 2007; 33: 219-223.

64. WHO (World Health Organization). Preventing disease through healthy environments. Action is needed on chemicals of major public health concern. Geneva, 2010.

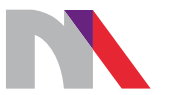

Ministry of Science and Higher Education

Republic of Poland

Generation of the DOI (Digital Object Identifier) - task financed under the agreement No. 618/P-DUN/2019 by the Minister of Science and Higher Education 